\title{
Impacts of Climate and Land Use Change on Hydrological Response in Gumara Watershed, Ethiopia
}

\author{
Achenafi Gebresilassie ${ }^{1}$, Yihun Dile Taddele ${ }^{2}$, Dereje Hailu ${ }^{1}$, Haimanote Bayabil ${ }^{3}$, and \\ Kibruyesfa Sisay ${ }^{4}$ \\ ${ }^{1}$ Addis Ababa University \\ ${ }^{2}$ Texas A\&M University System \\ ${ }^{3}$ University of Florida \\ ${ }^{4}$ United Nations Development Programme Ethiopia
}

August 28, 2020

\begin{abstract}
Climate and land-use change affect the hydrologic cycle by altering streamflow (SF), surface runoff (SR), base-flow (BF), and evapotranspiration (ET). The Lake Tana basin has experienced both land-use and climate change over the past 40 years, and this change can continue in the future. Several studies have addressed the separate impacts of either land-use or climate change on the watershed's hydrology, but few have explored the combined impacts. In this study, the SWAT model was applied to evaluate the combined impacts of land-use and climate change on hydrological responses in Gumara watershed. This study examined four land-use scenarios that include the present (2015) and projected (2050) land-use based on the business-as-usual trend (BAU), expansion of irrigation crop (EIC), and expansion of forestland (EFL). The climate variables were simulated using Weather Research and Forecasting (WRF) model for the baseline (2005-2015) and projected period (2045-2055) under RCP4.5 and RCP8.5 scenarios. The result showed that SR increase by $5.1 \%$ under BAU scenario while BF decrease by $6.5 \%$ without altering SF and ET noticeably. On the contrary, SF decrease by $12.5 \%$ and $5.2 \%$ respectively under EIC and EFL scenarios, while ET increase by $4.8 \%$ and $8.9 \%$ respectively under EIC and EFL scenarios. The simulated SF, SR, and ET under RCP8.5 may increase significantly by $34.3 \%, 51.8 \%$, and $12.2 \%$, respectively. Similarly, the simulated SF, SR and ET may increase significantly under the combination of all three land-use and RCP8.5 scenarios. The findings suggested that climate change will have a greater effect on hydrologic responses than land-use change. The expansion of agriculture and the wetter climate would exacerbate flooding, while the expansion of irrigation and forest offset SF increases. The results of this study can be useful to decision-makers and planners in the design of adaptive measures to climate and land-use change.
\end{abstract} Impacts of Climate and Land Use Change on Hydrological Response in Gumara Watershed,
Ethiopia

Achenafi Teklay ${ }^{1,}{ }^{*}$, Yihun T. Dile ${ }^{2}$, Dereje H. Asfaw ${ }^{3}$, Haimanote K Bayabil ${ }^{4}$, Kibruyesfa Sisay ${ }^{5}$

${ }^{1}$ University of Gondar, College of Agriculture and Environmental Sciences, Gondar, Ethiopia

${ }^{2}$ Spatial Science Laboratory, Ecosystem Science and Management Department, Texas A \& M University, College Station, TX, 77801, USA

${ }^{3}$ Addis Ababa Institute of Science and Technology, School of Environmental and Civil Engineering, Addis Ababa University, Addis Ababa, Ethiopia

${ }^{4}$ Agricultural and Biological Engineering, Tropical Research and Education Center, Institute of Food and Agricultural Sciences, University of Florida, Homestead, FL, 33031, USA 
${ }^{5}$ United Nations Development Programme, Addis Ababa, Ethiopia

Correspondence: Achenafi Teklay, University of Gondar, College of Agriculture and Environmental Sciences, Gondar, Ethiopia, P. Box 196, Ethiopia (achenafi.teklay@gmail.com)

\begin{abstract}
Climate and land-use change affect the hydrologic cycle by altering streamflow (SF), surface runoff (SR), base-flow (BF), and evapotranspiration (ET). The Lake Tana basin has experienced both land-use and climate change over the past 40 years, and this change can continue in the future. Several studies have addressed the separate impacts of either land-use or climate change on the watershed's hydrology, but few have explored the combined impacts. In this study, the SWAT model was applied to evaluate the combined impacts of landuse and climate change on hydrological responses in Gumara watershed. This study examined four land-use scenarios that include the present (2015) and projected (2050) land-use based on the business-as-usual trend (BAU), expansion of irrigation crop (EIC), and expansion of forestland (EFL). The climate variables were simulated using Weather Research and Forecasting (WRF) model for the baseline (2005-2015) and projected period (2045-2055) under RCP4.5 and RCP8.5 scenarios. The result showed that SR increase by 5.1\% under BAU scenario while BF decrease by $6.5 \%$ without altering SF and ET noticeably. On the contrary, $S F$ decrease by $12.5 \%$ and $5.2 \%$ respectively under EIC and EFL scenarios, while ET increase by $4.8 \%$ and $8.9 \%$ respectively under EIC and EFL scenarios. The simulated SF, SR, and ET under RCP8.5 may increase significantly by 34.3\%, 51.8\%, and 12.2\%, respectively. Similarly, the simulated SF, SR and ET may increase significantly under the combination of all three land-use and RCP8.5 scenarios. The findings suggested that climate change will have a greater effect on hydrologic responses than land-use change. The expansion of agriculture and the wetter climate would exacerbate flooding, while the expansion of irrigation and forest offset SF increases. The results of this study can be useful to decision-makers and planners in the design of adaptive measures to climate and land-use change.
\end{abstract}

Keywords: hydrological response; land-use change; climate change; SWAT; WRF

\title{
1 Introduction
}

Both climate and land-use change affect the spatial and temporal variability of the watershed hydrology through modifying streamflow, surface runoff, base-flow and evapotranspiration (Rahman et al. , 2015; Liu et al. , 2017). According to the Intergovernmental Panel on Climate Change report (IPCC, 2014), global average temperatures and frequency of heavy precipitation events are expected to increase in the mid- $21^{\text {st }}$ century. These changes will affect the hydrologic cycle through enhanced evaporation, peak flow, and flooding. Furthermore, land-use change seriously affects water resources mainly through partitioning of the rainfall amount into interception, evapotranspiration, infiltration, and soil moisture storage, thereby affecting the availability of watershed hydrology (Mishra et al. , 2010; Mango et al. , 2011). Human activities especially agricultural land expansion at the expense of forest cover have been the primary reason for the land-use change (Mottet et al. , 2006). The impact assessment study showed that interactions between landuse and climate could create serious challenges for water quantity and quality. Therefore, understanding the combined effects of land-use and climate change can be a basis for improved water resources management.

In recent years, many studies examined the combined impact of land-use and climate change on hydrologic processes (Koch et al. , 2015; Hyandye et al. , 2018; Aboelnour et al. , 2019). The findings from these studies consistently highlight the water balance components including streamflow, surface runoff, groundwater, and evapotranspiration are likely to be impacted by future land-use and climatic changes. However, the relative impacts of land-use and climate change may vary from place to place due to the rate and extent of changes in climate and land-use. For example, some studies have found that the hydrological processes are impacted more by climate change than land-use change (Mekonnen et al. , 2018; Aboelnour et al. , 2019), and 
other studies have indicated that the impacts of land-use change are more significant as compared to the impacts of climate change (Mwangi et al. , 2016; Yin et al. , 2017). The interaction between climate change and land-use change is non-linear (Jung et al. , 2011). For example, some studies reported that the increase in streamflow due to land-use change was amplified by wetting climate scenarios (Marhaento et al. , 2018), and other studies found that climate change could substantially offset runoff increment due to urbanization (Sunde et al. , 2018). This highlights the importance of considering the combination of scenarios to understand the impact of environmental changes in the future availability of water resources. Therefore, investigating the effects of changes in climate and land-use on watershed hydrology has a great practical significance; especially in the tropical region like Ethiopia, where climate and land-use change rapidly (Berihun et al. , 2019; Chimdessa et al. , 2019).

In Ethiopia, during the past four decades, there has been extensive land-use changes and intensification of climate change. The land-use studies across different parts of Ethiopia have shown that the coverage of cropland has been expanded extensively (Teferi et al. , 2013; Jemberie et al. , 2016; Gebremicael et al. , 2019). This land-use dynamic has resulted in a change in the fluxes of the hydrological cycle (Teklay et al. , 2018), which caused an increase in surface runoff and a decrease in soil moisture and evapotranspiration (Woldesenbet et al. , 2017; Gebremicaelet al. , 2019). Climate change may further intensify this process through alteration of the hydrological cycle (Bekele et al. , 2019). According to World Bank (2019), climate projections for Ethiopia indicate an overall increase in temperature and precipitation for all months, especially during the wet season. The changes in both temperature and precipitation exhibit remarkable regional variability as evident from the Lake Tana basin predict to experience a warmer and wetter climate in the future (Ayele et al. , 2016; Nigatu et al. , 2016).

Although the water resources in the Lake Tana basin is highly vulnerable to both land-use and climate change (Woldesenbet et al. , 2018), several studies have investigated the impact of either land-use change (Andualem and Gebremariam, 2015; Gumindoga et al. , 2015; Woldesenbet et al. , 2017; Gashaw et al. , 2018) or climate change (Abdo et al. , 2009; Dile et al. , 2013; Enyewet al. , 2014; Taye et al. , 2015; Ayele et al. , 2016) on the hydrological responses. Very few studies investigated the combined effect of land-use and climate change on water resources in the basin (McCartney and Girma, 2012; Woldesenbet et al. , 2018). Moreover, most of the studies which examined the impact of climate change on water resources have assumed that land-use remains static. On the other hand, studies that investigated the impact of landuse change rarely considered climate dynamics. However, land-use and climate in the future will change intensively due to urbanization, population growth, economic development, and global warming (McCartney and Girma, 2012). The expansion of cropland and deforestation accompanied by climate change may impose an unprecedented impact on watershed hydrology, whereas afforestation and water harvesting structure may modify the negative impact of climate change (McCartney and Girma, 2012). Gumara river is one of the tributaries in Lake Tana basin where small and large scale irrigation projects are planned to improve the livelihood of the community. However, there is inadequate information about land management practices in modifying the impact of climate change on water resources in the watershed level.

Therefore, this research is designed to investigate the combined and individual impact of land-use and climate change on the hydrological responses in Gumara watershed, Ethiopia. In this study, four land-use and three climate change scenarios were used for hydrological simulations using the SWAT model for the projected period and the reference period.

\section{Materials and Methods}

\subsection{Study area}

Gumara watershed is located in the northwestern part of Ethiopia between $37.63^{\circ}-38.18^{\circ}$ longitude and $11.57^{\circ}-11.90^{\circ}$ latitude. Gumara river originates from a small spring located near Guna Mountain and drains to the eastern part of Lake Tana (Figure 1). The catchment area of the Gumara river is $1269 \mathrm{~km}^{2}$. Gumara 
river is one of the main streams on the east side, flowing into Lake Tana. Elevation of Gumara watershed varies from 1794 and 3704 meter above sea level, with a mean elevation of $2272 \mathrm{~m}$. From the slope map, around $60 \%$ of the catchment area falls in the slope range from 0 to $15 \%$ and $32 \%$ of the area falls in the slope range of $15-30 \%$. The remaining $8 \%$ of the area has slopes steeper than $30 \%$.

The watershed has a tropical humid climate with distinct dry and wet seasons. The mean annual rainfall is $1387 \mathrm{~mm}$, of which about 70-90\% falls from June to September rainy season while less than 10\% during April and May. The long term average daily minimum and maximum temperatures are $9{ }^{\circ} \mathrm{C}$ and $28.5{ }^{\circ} \mathrm{C}$, respectively. The majority of the watershed area is covered by cultivated land (92\%), and the remaining area is covered by shrubs (3\%), grassland (4\%), and forest (1\%). The most dominant soil type is Haplic Luvisols (64\%) which is found in the midstream parts of the watershed. The second dominant soil is Eutric Vertisols which is found in the downstream parts. Chromic Luvisols mainly extends to downstream and upstream parts of the watershed. Eutric Fluvisols is the least common soil type $(<1 \%)$ in the watershed.

Figure 1

\subsection{Data availability}

Spatial and non-spatial data were collected for the hydrological model evaluation and future land-use modeling. Land-use maps of 30-m spatial resolution for the years 1985, 1995 and 2015 were available for Gumara watershed from Teklay et al. (2018). The soil map, streamflow and Gumara Irrigation Project plan were collected from the Ministry of Water, Irrigation and Electricity of Ethiopia (MoWIE, 1998, 2008). DEM data with a spatial resolution of $90 \mathrm{~m}$ was obtained from the Shuttle Radar Topographic Mission (SRTM). The meteorological dataset was collected from the National Meteorological Agency (NMA) of Ethiopia from five stations (Figure 1). The spatial road network and town map were available from Ethiopia Mapping Agency. The population size and agricultural management practices such as major crops, planting, harvesting and killing, tillage, and fertilize application data for the watershed were obtained from the Central Statistical Agency of Ethiopia and South Gondar Zone Agriculture Office (CSA, 2007; SGZOA, 2016).

\subsection{Hydrological model}

The Soil and Water Assessment Tool (SWAT) is a physically-based, computationally efficient, semidistributed model to simulate and predict the impacts of land management practices on water, sediment and agricultural chemical yields in large complex watersheds with varying soils, land-use, and management conditions over long periods (Neitschet al. , 2011). The model has been widely used in different watersheds across the world and proved to be an effective tool to examine hydrological responses to land-use and climate changes (Kumaret al. , 2017; Pandey et al. , 2017; Polanco et al. , 2017; Lee et al. , 2018). In the SWAT model, the target watershed is divided into sub-basins linked by the channel network, each sub-basin is further subdivided into several hydrological response units (HRUs) of homogeneous land-use, slope and soil characteristics. Hydrological components, nutrients and sediment yield are simulated at the HRU level and then aggregated for each sub-basin. The detailed model description is found in Neitsch et al. (2011).

The suitability of the SWAT model to estimate hydrologic processes to land-use change in Gumara watershed was assessed by Teklay et al.(2018). In this study, the SWAT model set-up followed the same settings as in the previous chapter. Therefore, this study presented only a summary of the model set-up and evaluation results. The watershed area was discretized into 22 sub-basins. These sub-basins were further discretized into HRUs by setting zero percent threshold level for land-use, slope, and soil. The Penman-Monteith method was chosen to calculate reference evapotranspiration (Gebre and Ludwig, 2015). The Soil Conservation Service Curve Number and the variable storage method were used to calculate surface runoff and flow routing, respectively.

Based on the previous studies in the region and literature survey (Setegn et al., 2008; Gebremicael et al. , 2013; Dileet al. , 2016), eighteen SWAT parameters were calibrated using the Sequential Uncertainty Fitting 
version 2 (SUFI-2) in the SWAT-Calibration and Uncertainty Procedure (SWAT-CUP) package (Arnoldet al. , 2012). The model was calibrated using monthly streamflow data for a period of fifteen years from 1990 to 2004. The calibration was performed through a "trial and error" process by manually adjusting the parameter ranges based on published literature (Van Griensven et al. , 2012; Dile et al. , 2016; Fentaw et al. , 2018). After calibration, the model was validated using streamflow data from 2005 to 2015. The performance of the SWAT model was assessed using two qualitative statistics recommended by Moriasi et al.(2007): NashSutcliffe Efficiency (NSE) value and Percent Bias (PBIAS). The results of the model calibration show that the simulated mean monthly streamflow in the calibration period agrees well with the observed records, with NSE and PBIAS values of 0.89 and $10.7 \%$, respectively. For the validation period, the NSE and PBIAS model performance of the SWAT model was 0.85 and $8.7 \%$, respectively. These findings are in agreement with previous studies in the region (Setegnet al., 2008; Dile et al. , 2016; Teklay et al. , 2018).

\subsection{Land-use scenario}

A scenario-based land-use change simulation can help to assess the potential impacts of land-use change on water resources in an uncertain future (Cao et al. , 2019). To examine the impact of land-use changes on the hydrological response in Gumara watershed, three future land-use scenarios for the year 2050 were developed. These scenarios were made to include the ongoing trends of land-use change within the study area, the future water resource development plan, and the idealized afforestation program. The land-use scenarios included:

\section{i. Business-as-usual (BAU) scenario}

In this scenario, the past land-use change trends were extrapolated into the future by assuming the past trends of land-use change will continue in the future. The BAU land-use scenario was simulated using a Module for Land-use Change Evaluation (MOLUSCE) component of QGIS. The module simulated land use land cover map based on a Monte Carlo Cellular-automata modeling approach. In recent years, this module has been widely used to simulate land-use changes (Rahman et al. , 2017; Ashaolu et al. , 2019). MOLUSCE is designed to analyze land-use changes and predict the future direction of change by using spatial change variables. The spatial variables including elevation, slope, and population density, as well as the distance to town and roads, were considered. These biophysical and socio-economic variables are widely used to analyze the change patterns and to extract effective information about the effects of human activities on land-use change (Doğan and Buğday, 2018). ArcGIS 10.1 software was used to prepare a raster spatial map. In this study, Artificial Neural Networks was used to model LULC transition potential between 1985 and 1995. The land-use map for 2015 was predicted based on the change transition area matrix. Then, both the present and predicted images of the year 2015 were compared for validation of the model. The classified land-use map of 2015 had a high overall accuracy of $86.4 \%$ and a kappa coefficient of 0.82 . Finally, the land-use for 2050 was predicted using a fitted model and transition matrix generated between 1995 and 2015 land-use maps.

\section{ii. Expansion of Irrigation Crop (EIC) scenario}

The future water resource development plan was considered in the EIC scenario. Gumara Irrigation Project map was scanned from the feasibility study document from the Ministry of Water, Irrigation and Electricity of Ethiopia (MoWIE, 2008). The scanned map was converted into a digital map using the Geo-referencing tool in ArcGIS. A dam is planned on the Gumara River at the midstream part of the watershed which covers a $3.51 \mathrm{~km}^{2}$ area at the full reservoir level. The stored water will then irrigate about $14.0 \mathrm{~km}^{2}$ land at the downstream side of the watershed. The EIC scenario was developed by replacing the present land-use pixels with irrigated cropland and reservoir pixels. Tomato, onion, and maize are the most widely cultivated crop types in the watershed (SGZOA, 2016). In the SWAT modeling, the whole irrigation farm was seeded to grain the three crops with equal proportion. The planting data started on January 1 of every simulation year.

\section{iii. Expansion of Forestland (EFL) scenario}


Expansion of forestland (EFL) scenario is an idealized land-use condition for the 2050 period. The EFL scenario was developed by assuming that the forest area will expand in the future especially on sloppy areas. The agriculture and shrub-land area on a slope greater than $15 \%$ are replaced by forest land-use. In this scenario, only the grassland and urban area were preserved.

\subsection{Climate scenario}

The baseline and future climate variables used in this study were simulation output from the Weather Research and Forecasting (WRF) model as presented in the previous chapter. GCMs data has too low spatial resolution for hydrological applications (Hurkmans et al. , 2010). Thus they were dynamically downscaled using the WRF model in three steps. First, the WRF output with a resolution of $36 \mathrm{~km}$ was obtained from the outer domain, which was reduced to $12 \mathrm{~km}$ (intermediate domain) and $4 \mathrm{~km}$ (inner domain) (Teklay et $a l ., 2019)$. In this study climatic data (rainfall and temperature) from the simulation of the internal domain were considered in the hydrological modeling processes.

The future scenarios were based on Representative Concentration Pathways (RCPs) radiative forcing as defined by the IPCC (2014). This study used RCP4.5 and RCP8.5 emission scenarios. The RCPs are named according to radiative forcing target level for 2100. The radiative forcing estimates are based on the forcing of greenhouse gases and other forcing agents. The RCP4.5 is a stabilization scenario without an overshoot pathway to $4.5 \mathrm{~W} / \mathrm{m}^{2}$ after 2100 . The total radiative forcing under RCP4.5 is stabilized before 2100 by the employment of a range of technologies and strategies for reducing GHG emissions. The RCP8.5 refers to high GHGs concentration levels and characterized by increasing GHG emissions over time, leading to a radiative forcing of $8.5 \mathrm{~W} / \mathrm{m}^{2}$ at the end of the century.

Compared to observations, the baseline climate dataset had some errors. This model bias need to be corrected by using observation climate data. For this purpose, five observation stations within and around Gumara watershed were used. The biases in rainfall simulation were corrected by power transformation (PT) method, whereas biases in temperature were corrected by variance scaling (VS). The bias correction was employed separately at each meteorological station. To evaluate the bias correction performance, the average daily observation and WRF simulation (before and after bias correction) were compared using statistical measures such as correlation coefficient (r) and root mean square error (RMSE). While bias correction improved overall performances of the WRF model in simulating rainfall and temperature; there were differences in model evaluation statistics (Figure A1 and Table A1). For temperature, bias-corrected mean values were very close to the observed. After bias correction, the RMSE was significantly reduced from $2.99{ }^{\circ} \mathrm{C}$ to $1.53{ }^{\circ} \mathrm{C}$ and $2.69{ }^{\circ} \mathrm{C}$ to $1.37{ }^{\circ} \mathrm{C}$ for maximum and minimum temperature, respectively, whereas RMSE was slightly decreased from 7.86 to $7.05 \mathrm{~mm} /$ day for rainfall. The bias-corrected data also showed a good agreement with observed data, especially for temperature. The correlation coefficients between observed and simulated data were significantly improved from 0.72 to 0.85 for maximum temperature and from 0.68 to 0.82 for minimum temperature, while it did not show significant improvement for precipitation correction. These results suggested that bias-corrected output was acceptable and consistent with previous studies (Sisay et al. , 2017; Goshime et al. , 2019).

\subsection{Combined land-use and climate change scenario}

The combination of four land-use scenarios (present, BAU, EIC, and EFL) and three climate scenarios (baseline, RCP4.5, and RCP8.5) leads to 12 (1 reference +11 future) scenarios, for which hydrologic responses were simulated using the calibrated SWAT model. For the reference period (2005-2015), the SWAT model used bias-corrected baseline climate data and present land-use of 2015. Table 1 shows the 12 scenarios that implemented in the study by categorizing the impacts of land use land cover change alone (LULCC), climate change alone (CC), and combined land use land cover and climate change (LULCC_CC) scenarios on hydrological responses. For each scenario, four water balance components, namely streamflow (SF), surface runoff (SR), base-flow (BF) and evapotranspiration (ET) were analyzed and compared to the reference 
conditions. A Student's t-test at a 95\% confidence level was employed to assess the significance of the difference between the reference and scenario simulations.

Table 1

\section{Results}

\subsection{Land-use change}

The most commonly distributed land-use type in 2050 under BAU is agriculture (Table 2). Compared to the present land-use (2015), BAU scenario grassland, shrub-land and forestland decreased by $1.6 \%, 2.6 \%$ and $0.3 \%$, respectively, while agriculture and urban increased by $4.3 \%$ and $0.2 \%$, respectively (Table 2 ). In the downstream and upstream parts of the watershed, grassland and shrub-land areas were mainly converted into agriculture (Figure 2). The results of agriculture and urban land expansion in the BAU scenario agrees with Gashaw et al. (2018) study in the Upper Blue Nile basin.

Under EIC, land-use in 2050 is predominantly agriculture, followed by irrigation crops, shrub-land, grassland, water, forestland, and urban. Compared to the present land-use, agriculture, grassland and shrub-land decreased by $9.2 \%, 1.0 \%$ and $0.2 \%$, respectively, while the new land-use, such as irrigation crop and water, covered the watershed area by $9.3 \%$ and $0.9 \%$, respectively. However, forestland and urban land coverage remain static in the future. Figure 2 shows that, under EIC, the irrigation command area was located in the downstream part and the reservoir was found in the midstream part of the watershed.

Table 1

Under EFL, land-use in 2050 is mainly agriculture, followed by forestland, grassland, shrub-land, and urban. Compared to the present land-use, agriculture and shrub-land decreased by $36.1 \%$ and $3.1 \%$, respectively, while forestland coverage significantly increased by $39.2 \%$. Figure 2 shows that, under EFL, reduction of shrub-land found in the midstream part of the watershed, while the expansion of forest and reduction of agriculture occurred in the entire watershed.

Figure 2

\subsection{Climate change}

The projected monthly rainfall shows inconsistent directions and magnitude of change between RCP4.5 and RCP8.5 scenarios. However, as shown in Figure 3a, the mean monthly rainfall may increase during the dry season (February and April) while it may decrease in August and November under RCP4.5 and RCP8.5 scenarios. The mean annual rainfall in the study watershed is projected to increase by $73.7 \mathrm{~mm}(5 \%)$ under RCP4.5 and $376.5 \mathrm{~mm}(25.7 \%)$ under RCP8.5 (Figure 3a). Under RCP8.5, rainfall increase may occur in most months of the year. In RCP4.5, rainfall may decrease during the rainy months (June to September) and the dry months (October and November). On the contrary, rainfall increase under RCP8.5 mainly concentrated in the rainy months (June and July). In spring, rainfall is projected to increase by $320.6 \mathrm{~mm}(172.5 \%)$ and $84.5 \mathrm{~mm}(45.5 \%)$ under RCP4.5 and RCP8.5 scenarios, respectively. However, rainfall under RCP4.5 may decrease by $176.2 \mathrm{~mm}(17.4 \%)$ and $86.3 \mathrm{~mm}(34.6 \%)$ in summer and autumn season, respectively.

\section{Figure 3}

The simulated minimum temperature shows a consistent increase in all months under both RCP4.5 and RCP8.5 scenarios (Figure 3b). The mean annual minimum temperature is projected to increase by $1.5{ }^{\circ} \mathrm{C}$ and $2.0{ }^{\circ} \mathrm{C}$ under $\mathrm{RCP} 4.5$ and $\mathrm{RCP} 8.5$, respectively. The monthly minimum temperature increases under RCP4.5 is between $0.3{ }^{\circ} \mathrm{C}$ and $3.5^{\circ} \mathrm{C}$ with the maximum increase in December, while minimum temperature increases under RCP8.5 ranged from $1.1{ }^{\circ} \mathrm{C}$ to $2.8{ }^{\circ} \mathrm{C}$ with the maximum increase in March. Unlike minimum temperature, the simulated maximum temperature shows a distinct direction of changes between RCP 4.5 and 
RCP8.5 scenarios in some months. Figure 3c shows an increase of the simulated maximum temperature in all months under RCP8.5, whereas maximum temperature under RCP4.5 may decrease in January, February and April. Under RCP4.5, the monthly maximum temperature may increase by $0.9{ }^{\circ} \mathrm{C}$ to $3.2{ }^{\circ} \mathrm{C}$, and decrease by $0.5^{\circ} \mathrm{C}$ to $1.1{ }^{\circ} \mathrm{C}$. Under RCP 8.5 , the magnitude of increase in maximum temperature varies between 0.6 ${ }^{\circ} \mathrm{C}$ and $3.7^{\circ} \mathrm{C}$. The mean annual maximum temperature is expected to increase by $1.7^{\circ} \mathrm{C}$ and $2.6{ }^{\circ} \mathrm{C}$ under RCP4.5 and RCP8.5 scenarios, respectively. It is noted that the increase in maximum temperature is higher than the increase in minimum temperature. The increase in mean annual minimum/maximum temperature under RCP8.5 is larger than that under RCP4.5 because the RCP8.5 scenario represents a higher radiative force (Wulong et al. , 2018). These results are in agreement with results from previous studies in the Gumara watershed (Gebre and Ludwig, 2015; Ayele et al. , 2016; Melke and Abegaz, 2017).

\subsection{The impact of land-use change on hydrologic response}

To evaluate the impacts of land-use change, hydrological processes were simulated using the calibrated SWAT model under four land-use (PER in 2015 and BAU, EFL, and EIC in 2050) scenarios with baseline climate. The relative change between the present and future land-use in streamflow (SF), surface runoff (SR), baseflow (BF), and evapotranspiration (ET) are shown in Table 3 and Figure 4. Compared to the REF simulation, BAU scenario show marginal increase in mean annual SF $(0.4 \%)$, while a decrease in SF is predicted under EFL $(5.2 \%)$ and EIC (12.5\%). Similarly, the mean annual SR under EFL and EIC scenario is predicted to decrease by $10 \%$ and $7.9 \%$, respectively, whereas SR under BAU is expected to increase by $5.1 \%$. The mean annual BF under EFL is slightly higher than that of under present land-use. However, agriculture practices in both rain-fed and irrigation under EIC scenario can significantly decrease the mean annual BF as high as $19 \%$. In BAU and EIC scenarios, BF contribution to $\mathrm{SF}$ is $38 \%$, which is lower than $\mathrm{BF}$ contribution under present land-use. The mean annual ET under EFL and EIC is likely to increase by $8.9 \%$ and $4.9 \%$, respectively, while BAU scenario yields a marginal decrease $(0.5 \%)$ in ET. The mean annual ET account for $37 \%, 41 \%$ and $39 \%$ of the mean annual rainfall, respectively, under BAU, EFL and EIC scenarios. Both EFL and EIC scenarios have a slightly higher tendency on the rainfall partitioned into ET, whereas BAU scenario has a slightly lower tendency compared to the present land-use.

Table 3

On monthly scale, the simulated SF under BAU scenario is slightly higher (up to $3 \mathrm{~mm}$ ) than the REF simulation during the main rainy season (June to August) and similar to the REF simulation during the dry season (Figure 4a). SF under EFL may decrease from May to September, with the largest decrease of 15.8 $\mathrm{mm}$ in July. Under EIC scenario, SF is projected to decrease significantly from July to October. Regarding other hydrological processes, the increase of agriculture by the expense of shrub and grassland under BAU depict a trend of increasing SR and decreasing BF and ET from May to September. Under EFL, BF is projected to increase during the end of summer (August) and late-autumn (September). However, ET under EFL may increase consistently in most months, with the largest increase of $10.6 \mathrm{~mm}$ in September (Figure 4d). Under EIC, BF may decrease by up to $56.6 \mathrm{~mm}$ during the rainy months (July to September) and late-rainy month (October), while ET may increase in most months. However, ET increases in January and February are significantly higher than that in other months, which may relate to the crop growth stage.

Figure 4

\subsection{The impact of climate change on hydrologic response}

To assess the impacts of climate change, hydrological processes were simulated using the calibrated SWAT model under three climate scenarios (Baseline, RCP4.5 and RCP8.5) with the PRE land-use. The simulated hydrological components for the projected period under RCP4.5 and RCP8.5 scenarios were compared to the corresponding values in the baseline period. Overall, an average of about $74 \mathrm{~mm}$ and $377 \mathrm{~mm}$ more rainfall per year was estimated to fall in the watershed in the future under RCP4.5 and RCP8.5 scenarios, respectively (Table 4). From the total annual rainfall, 99\% contributed to SF and ET in both the reference 
(REF) and future simulation (RCP4.5 and RCP8.5). The remaining $1 \%$ contributed to groundwater recharge. Under RCP4.5, about $81 \%$ of the rainfall increase contribute to ET increase $(60 \mathrm{~mm})$. The remaining $19 \%$ contributed to SF $(13 \mathrm{~mm})$ and groundwater recharge $(1 \mathrm{~mm})$. On the contrary, $81 \%$ of the rainfall increase under RCP 8.5 contribute to SF increase $(308 \mathrm{~mm})$ and $18 \%$ of the rainfall increase contribute to ET increase $(67 \mathrm{~mm})$. The remaining $1 \%$ contribute to groundwater recharge increase $(2 \mathrm{~mm})$. The simulated SR under RCP4.5 and RCP8.5 scenarios is greater than the reference simulation. However, SR under RCP8.5 (51.8\%) is significantly higher than the reference simulation. The mean annual BF under RCP4.5 may decrease by $6.8 \%$, whereas $\mathrm{BF}$ under RCP 8.5 may increase by $9.2 \%$. In RCP 4.5 and RCP 8.5 simulations, $\mathrm{BF}$ contribution to the watershed $\mathrm{SF}$ is $38 \%$ and $33 \%$, respectively.

Table 4

As can be seen in Figure 5, the peak flow under RCP4.5 is projected to decrease, while a higher and earlier peak flow (shifting from August to July in the future) is simulated under RCP8.5. This may be due to the future rainfall decreases under RCP4.5 and increases under RCP8.5 during the main rain months (June and July). The simulated SF under RCP4.5 is likely to increase from February to May with the largest increase of $85.9 \mathrm{~mm}$ in April (Figure 5a). However, SF may decrease by up to $81.5 \mathrm{~mm}$ during the rainy months (July to September) and up to $14.9 \mathrm{~mm}$ during the dry period (October to January). Under RCP8.5, SF is expected to increase from February to July with the largest increase of $265 \mathrm{~mm}$ in July, while SF decreases are projected to occur during the dry period (November to January) and rainy month (August). With the exception of magnitude, the direction of monthly changes in SR is closely mirrored the changes simulated for SF (Figure 5b). Under RCP4.5, BF contribution to SF may increase during the dry months (March to May), while the contribution may decrease from July to September (Figure 5c). However, under RCP8.5, the highest BF increase and decrease may occur during the rainy months (July and August), which corresponds to the rainfall changes during rainy months. The simulated ET under both scenarios is larger than the reference simulation in most months (Figure 5d). Under RCP4.5, the largest increase in ET is projected to occur in April (48.1 mm) while the largest decrease may occur in November $(18.2 \mathrm{~mm})$. Under RCP8.5, a maximum increase in ET is predicted in March $(33.4 \mathrm{~mm})$, whereas the highest decrease in ET will occur in December $(6.1 \mathrm{~mm})$.

Figure 5

\subsection{The combined impact of land-use and climate change on hydrologic response}

To assess the combined impacts of land-use and climate change on hydrological processes, six simulations were carried out by using a combination of three land-use and two climate change scenarios. The changes in hydrological processes were profound in the combined land-use and climate scenarios (Table 5 and Figure 6). The mean annual SF is projected to increase under BAU4.5, BAU8.5, EFL8.5 and EIC8.5 scenarios. The largest increase in SF may occur under BAU8.5 (34.9\%). Conversely, SF is projected to decrease under EFL4.5 and EIC4.5 scenarios, with the largest decrease of $11.9 \%$ under EIC4.5. The combination of land-use and climate scenario will have an additive effect on SF simulation. For example, SF increase under BAU8.5 $(34.9 \%)$ is the simple addition of SF increase under BAU land-use scenario alone (0.4\%, Table 3$)$ and RCP 8.5 climate scenario alone (34.3\%, Table 4$)$. The RCP8.5 climate scenario in combination with land-use scenarios has a considerable influence on SR. Overall, SR under BAU8.5, EFL8.5 and EIC8.5 are significantly larger than the reference simulation. Such increases in SR are mainly derived by RCP8.5 rainfall increases. The expansion of irrigated cropland (EIC) combined with climate change scenarios may substantially decrease BF. Similarly, the combination of BAU and RCP4.5 will yield significantly lower BF compared to the reference simulation. The EFL8.5 scenario produce the largest increase in BF (12.2\%), while the EIC4.5 scenario yield the largest decreases in BF (26.8\%).

Table 5

The result shows that all the combined scenarios increase mean annual ET, with the largest increase of $21.1 \%$ under EFL8.5 and the smallest increase of $10.1 \%$ under BAU4.5. The increases in mean annual ET 
under the combined land-use and climate change scenarios is more pronounced than that under land-use and climate scenario alone. For example, the increases in ET under EFL (49 mm) alone (Table 3) and RCP4.5 $(60 \mathrm{~mm})$ alone (Table 4) are not significant, but the combination of the two scenarios (EFL4.5) may produce a significantly larger mean change $(116 \mathrm{~mm})$. The result also shows that the combined impacts of land-use and climate change are additive to the separate impacts. For example, ET decrease of $3 \mathrm{~mm}$ under BAU alone (Table 3) and ET increase of $67 \mathrm{~mm}$ under RCP8.5 alone (Table 4) result in an increase of $64 \mathrm{~mm}$ under BAU8.5 (Table 5). However, the combined land-use and climate change impacts is slightly greater than the sum of the separate changes under EFL4.5 and EIC4.5 scenarios.

The changes in SF show increases in most months under the combined land-use and RCP8.5 scenarios (Figure 6a). The greatest increase will occur in July $(267 \mathrm{~mm})$ under BAU8.5. However, in July, SF under the combination of RCP4.5 and land-use scenarios may decrease due to rainfall decrease under RCP4.5 (Figure 3a). Moreover, in August, SF under all the combined scenarios are substantially lower than the reference simulation, which corresponds to monthly rainfall distribution under both climate scenarios. This indicate that the direction of monthly SF changes is mainly driven by climate change scenarios. In most months, SF change between land-use scenarios are very small compared to changes between emission scenario (Figure 6a). The change in monthly SR follow similar pattern as for SF; the mean increase of up to $227 \mathrm{~mm}$ and decrease of up to $46 \mathrm{~mm}$ may occur in July under BAU8.5 and EFL4.5 scenarios, respectively (Figure 6b). BF under all the combined scenarios are projected to increase during the dry months from March to May, whereas it may decrease substantially during August (Figure 6c). The directions of change in the monthly BF under different scenarios are similar to those under the climate change scenario alone. ET under all the combined scenarios show increases in most months. However, the increases in March and April are substantially higher than other months. From February to May, ET under all the combined scenarios is larger than that under the reference simulation. This is similar to what is found with the climate simulations alone. The direction and magnitude of changes in ET are mainly driven by the climate change scenarios. However, during June to September, the direction of change in ET follows similar patterns to those under EFL land-use scenario. For example, ET under EFL4.5 is slightly larger $(1.2 \mathrm{~mm})$ than the reference simulation in June, which result from the counterbalance between ET increase under EFL alone $(6.6 \mathrm{~mm})$ and a decrease under RCP4.5 alone $(7.2 \mathrm{~mm})$.

Figure 6

\section{Discussion}

\subsection{The impact of land-use change on hydrological response}

The BAU scenario had less forest and shrub-land area than the PRE land-use, and its total agriculture area increase by $4.4 \%$. As a result of this, the simulated SR may increase and BF may decrease in the future under BAU scenario. Agriculture areas have been positively correlated to SR. For example, in the Upper Blue Nile basin, Woldesenbet et al.(2017) found a strong positive correlation between the area of agriculture and mean annual runoff. This result is consistent with previous studies where the increase of agriculture coverage resulted in SR increase owing to reduced percolation and evaporation (Gashawet al. , 2018; Teklay et al. , 2018; Berihun et al. , 2019). The expansion of agriculture (BAU) increase the contribution of SR to SF (Table 3). The cultivation practices could form soil crusting, which result in low infiltration and BF (Rahbeh et al. , 2013).

The SF decrease under EFL can be attributed to lower SR due to increasing forestland which improve the water holding capacity of the soil, infiltration and recharge. This result is in agreement with findings that show forestland expansion reduce SF and SR (Guzha et al., 2018; Gebremicael et al. , 2019). A decrease in SF and SR are also attributed to the increase of water retained in the watershed and increase of ET as forest cover increase. These results are comparable with those from Woldesenbet et al. (2018) in the Upper Blue Nile basin, Ethiopia and Bossa et al. (2014) in the West Africa region. The increase in ET due to forest 
expansion has been reported by Hyandye et al. (2018), wherein they found that forest expansion (+7\%) in Ndembera watershed located in Tanzania increased ET by approximately $8 \%$.

The introduction of irrigated cropland and water reservoir under EIC may decrease SF during the main rainy season (Figure 4a). This is due to the diversion of SF into the reservoir to stores water for the dry season irrigation demand. Evaporation from the reservoir may contribute to ET increase. Besides, ET increase under the expansion of irrigation crops may result from the high leaf area index and transpiration demand for irrigation crops. This result agrees well with the study by Hyandyeet al. (2018) and who reported that ET would increase by $30 \mathrm{~mm}$ due to the expansion of irrigated onion and rice farms by $10 \%$.

Overall, most of the water balance component changes between the present and future land-use scenarios were insignificant ( $p>0.05$, Table 3 ), since the converted land-use areas were smaller than the threshold level which cause significant change on hydrological processes. These results agree with Li et al. (2007) study in the West African basins. They simulated the hydrological impact of land-use change and found that deforestation below $50 \%$ has no significant impact on streamflow and water yield; however, the water yield was dramatically increased when land-cover change exceeds this threshold. In other regions, Eckhardt et al. (2003) also quantified the minimum proportion of a watershed that has to undergo a land-use change to detect apparent water balance differences. They found that the mean surface runoff amount was changed when approximately $20 \%$ of the watershed area was changed.

\subsection{The impact of climate change on hydrological response}

The future climate simulations show increases in mean annual rainfall by about $74 \mathrm{~mm}$ under RCP4.5 and $377 \mathrm{~mm}$ under RCP8.5, yet some simulation may decrease from June to November under RCP4.5 and from November to January, and in May and August under RCP8.5. The mean annual SF is simulated to increase mainly due to the increase of mean annual rainfall. However, the relationship between rainfall and SF is complicated and non-linear. The projected rainfall change can be amplified in the SF hydrograph (Figure $5 a)$. This amplification may occur when the projected rainfall increases concentrate on rainy months of June and July (Figure 3a) when soil moisture is relatively high in the study watersheds. The increase in streamflow due to rainfall increment was also discussed by Pandey et al. (2017); they revealed that a $28 \%$ increase in annual rainfall resulted in streamflow increase by approximately $49 \%$ from their study in the Armor watershed in Godavari river basin, India. Besides, the temporal distribution of rainfall also affects peak flow and SF change. SF change under RCP4.5 is very small, owing to the rainfall decline in the main rainy months (June to September). However, rainfall increase under RCP4.5 concentrate in the dry season (March and April), which leads to an increase in rainfall partitions to percolation. As a consequence, ET is projected to increase mainly attributed to the soil moisture evaporation (Figure 5d). This indicate that warmer temperature shifted rainfall increase into ET increase, which is consistent with the findings of Mango et al.(2011) in the East African watershed. They found that the modest increases in precipitation are partitioned largely to increase ET. The monthly ET changes are almost similar pattern with monthly rainfall changes. This result agrees with Marhaento et al. (2018) study in Indonesia, who found that ET simulation highly influenced by rainfall change compared to temperature change. However, Hyandye et al.(2018) found different results from this study. They found that changes in ET mainly associated with changes in temperature.

\subsection{The combined impact of land-use and climate change on hydrological respon-} se

The results show that the combined land-use and climate change have a more noticeable effect on SF and SR. The significant increase in rainfall and expansion of agriculture will have an additive impact on SF and SR (Legesse et al. , 2010; Mango et al. , 2011). Moreover, the highest SF increase during the main rainy months may cause flooding in the future. Afforestation in the steep slope area is recommended to reduce SR which is the major cause of flooding and soil erosion (Nyssen et al. , 2004). The forest expansion in the sloppy areas improve rainfall partitioned into infiltration, subsequently reduce SR (Table 5). The results related to forest 
expansion effect on water balance components are consistent with the findings of Woldesenbetet al. (2018) in the Upper Blue Nile basin and Marhaento et al. (2018) in the Samin catchment. Besides, conserving the rainy season excess water for the dry season irrigation play a substantial role in reducing SF (Table 5). However, irrigation practice may increase SR during the dry season (Figure 6b) and will cause soil erosion. Therefore, different water management practices must be implemented to reduce SR.

The expansion of forest and irrigation along with climate change may increase ET significantly (Table 5). The slight increase of rainfall alone (RCP4.5) does not show significant ET change, whereas both climate and land-use change have a significant impact on ET (Table 5). The combination of climate change and land-use (BAU) have additive impacts on ET. However, ET increase under forest and irrigation expansion (EFL and EIC) is amplified by projected future climate (RCP4.5), which result from plant transpiration and evaporation from soil moisture and canopy interception. This result is consistent with the findings of Marhaentoet al. (2018). However, the climate change signal had a dominant effect on simulated water balance components. Similar conclusions have been reported in the Upper Blue Nile basin (Mekonnen et al. , 2018). The combined impacts of climate and land-use change show a non-linear effect on water balance components, which is consistent with results found for climate and land-use change impacts on hydrological responses in Hinkson Creek Watershed in central Missouri (Sunde et al. , 2018).

\section{Conclusions}

This study presented an integrated modeling approach for assessing the separate and combined effects of landuse and climatic changes on hydrologic processes in Gumara watershed. The study used Weather Research and Forecasting (WRF) model to downscale GCM output from the latest generation of climate models (CMIP5), Land-use Change Evaluation (MOLUSCE) module to generate future land-use scenarios, and a process-based watershed hydrologic model (SWAT). In this study, four land-use and three climate scenarios were developed and used as input for the SWAT model to determine the relative and the interaction impacts of the two changes.

The results suggest that most of the combined scenarios have a pronounced effect on streamflow and surface runoff. However, climatic changes could have a larger impact than land-use change on streamflow and surface runoff. When the expansion of agriculture scenario (BAU) is replaced by the expansion of forest scenario (EFL), the mean annual surface runoff may decrease by $14.7 \%$ and $10.8 \%$ under RCP 4.5 and RCP 8.5 scenarios, respectively, while the mean annual base-flow may increase by about $9.3 \%$ and $10.1 \%$ under RCP4.5 and RCP8.5, respectively. The monthly changes in streamflow are mainly driven by climate change scenarios. Moreover, the influence of the combined effect on streamflow does not vary directionally in most months. The largest uncertainty in streamflow simulation (-99.3 $\mathrm{mm}$ to $267 \mathrm{~mm}$ ) may occur in July which can be attributed to the uncertainty of rainfall prediction $(-102.3 \mathrm{~mm}$ to $235.5 \mathrm{~mm})$. The result also indicates that the effect of climate change on the mean annual evapotranspiration is extremely larger than the effect of landuse change. The increases of evapotranspiration under climate change scenarios are augmented by increases under the expansion of forest and irrigation scenarios, while the marginal decrease in evapotranspiration under the expansion of agriculture scenario is offset by increases under climate change scenarios. Similarly, the magnitude and direction of monthly changes in evapotranspiration are mainly driven by climate change scenarios, but the forest expansion effect is most influential from June to September.

In general, the results were not conclusive but provide insight into the future hydrologic scenario of Gumara watershed. Projections of future availability of water resources contain a large number of uncertainties, and this work demonstrates that the relative and the combined effect of land-use and climate change on water balance components. Moreover, the model output can provide useful information about the contribution of each land-use to water balance components as well as to water balance dynamics due to climate change. The results suggest that water resources in the Gumara watershed may increase or decrease in the mid- $21^{\text {st }}$ century as a consequence of climate and land-use changes, it is a great difficulty to ascertain an accurate magnitude of change. 


\section{Acknowledgements}

This study was financially supported by the International Foundation for Science [grant number W/59261]. The National Meteorological Agency of Ethiopia is gratefully acknowledged for providing rainfall and temperature data. We also acknowledge the financial and software support provided by the University of Gondar and Addis Ababa University.

\section{Data Availability}

Data used to support our findings are available from the corresponding author upon request.

\section{Appendix A}

Figure A1

Table A1

\section{References}

Abdo KS, Fiseha BM, Rientjes THM, Gieske ASM, Haile AT. 2009. Assessment of climate change impacts on the hydrology of Gilgel Abay catchment in Lake Tana basin, Ethiopia. Hydrological Processes 23(26): 3661-3669 DOI: 10.1002/hyp.7363

Aboelnour M, Gitau MW, Engel BA. 2019. Hydrologic response in an urban watershed as affected by climate and land-use change. Water (Switzerland) 11 (8): 1-23 DOI: 10.3390/w11081603

Andualem TG, Gebremariam B. 2015. Impact of Land Use Land Cover Change on Stream Flow and Sediment Yield : A Case Study of Gilgel Abay Watershed, Lake Tana Sub-basin, Ethiopia. International Journal of Technology Enhancement and Emerging Engineering Research 3 : 28-42

Arnold JG, Moriasi DN, Gassman PW, Abbaspour KC, White MJ, Srinivasan R, Santhi C, Harmel RD, van Griensven A, Van Liew MW, et al. 2012. SWAT: Model Use, Calibration, and Validation. Transactions of the ASABE 201255 (4): 1491-1508

Ashaolu ED, Olorunfemi JF, Ifabiyi IP. 2019. Assessing the Spatio-Temporal Pattern of Land Use and Land Cover Changes in Osun Drainage Basin, Nigeria. Journal of Environmental Geography12 (1-2): 41-50 DOI: 10.2478/jengeo-2019-0005

Ayele HS, Li M-H, Tung C-P, Liu T-M. 2016. Assessing Climate Change Impact on Gilgel Abbay and Gumara Watershed Hydrology, the Upper Blue Nile Basin, Ethiopia. Terrestrial, Atmospheric and Oceanic Sciences 27 (6): 1005-1018 DOI: 10.3319/tao.2016.07.30.01

Bekele D, Alamirew T, Kebede A, Zeleke G, Melesse AM. 2019. Modeling Climate Change Impact on the Hydrology of Keleta Watershed in the Awash River Basin, Ethiopia. Environmental Modeling and Assessment 24 : 95-107 DOI: 10.1007/s10666-018-9619-1

Berihun ML, Tsunekawa A, Haregeweyn N, Meshesha DT, Adgo E, Tsubo M, Masunaga T, Fenta AA, Sultan D, Yibeltal M, et al. 2019. Hydrological responses to land use/land cover change and climate variability in contrasting agro-ecological environments of the Upper Blue Nile basin, Ethiopia. Science of the Total Environment 689 : 347-365 DOI: 10.1016/j.scitotenv.2019.06.338

Bossa AY, Diekkruger B, Agbossou EK. 2014. Scenario-based impacts of land use and climate change on land and water degradation from the meso to regional scale. Water 6 (10): 3152-3181 DOI: 10.3390/w6103152 
Cao M, Zhu Y, Quan J, Zhou S, Lu G, Chen M. 2019. Spatial Sequential Modeling and Predication of Global Land Use and Land Cover Changes by Integrating a Global Change Assessment Model and Cellular Automata.Earth's Future 7 : 1102-1116 DOI: 10.1029/2019EF001228

Chimdessa K, Quraishi S, Kebede A, Alamirew T. 2019. Effect of land use land cover and climate change on river flow and soil loss in Didessa River Basin, South West Blue Nile, Ethiopia. Hydrology 6(1) DOI: 10.3390/hydrology6010002

CSA. 2007. Summary and statistical report of 2007 population and housing census of Ethiopia. Central Statistical Agency, Addis Ababa, Ethiopia

Dile YT, Berndtsson R, Setegn SG. 2013. Hydrological Response to Climate Change for Gilgel Abay River, in the Lake Tana Basin - Upper Blue Nile Basin of Ethiopia. PLoS ONE 8 (10): 1-13 DOI: 10.1371/journal.pone.0079296

Dile YT, Daggupati P, George C, Srinivasan R, Arnold J. 2016. Introducing a new open source GIS user interface for the SWAT model.Environmental Modelling and Software 85 : 129-138 DOI: $10.1016 /$ j.envsoft.2016.08.004

Doğan S, Buğday E. 2018. Modeling of Temporal and Spatial Changes of Land Cover and Land Use by Artificial Neural Networks : Kastamonu Sample. Journal of Bartin Faculty of Forestry 20 (3): 653-663 DOI: $10.24011 /$ barofd.467974

Eckhardt K, Breuer L, Frede H. 2003. Parameter uncertainty and the significance of simulated land use change effects. Journal of Hydrologic Engineering 273 : 164-176

Elshamy ME, Seierstad IA, Sorteberg A. 2009. Impacts of climate change on Blue Nile flows using biascorrected GCM scenarios. Hydrology and Earth System Sciences 13 (5): 551-565 DOI: 10.5194/hess-13-5512009

Enyew B, Van Lanen H, Van Loon A. 2014. Assessment of the Impact of Climate Change on Hydrological Drought in Lake Tana Catchment, Blue Nile Basin, Ethiopia. Journal of Geology \&3 Geosciences 3(6): 1-17 DOI: $10.4172 / 2329-6755.1000174$

Fentaw F, Mekuria B, Arega A. 2018. Impacts of Climate Change on the Water Resources of Guder Catchment, Upper Blue Nile, Ethiopia. Waters 1 (1): 16-29 DOI: 10.31058/j.water.2018.11002

Gashaw T, Tulu T, Argaw M, Worqlul AW. 2018. Modeling the hydrological impacts of land use/land cover changes in the Andassa watershed, Blue Nile Basin, Ethiopia. Science of the Total Environment619-620 : 1394-1408 DOI: 10.1016/j.scitotenv.2017.11.191

Gebre SL, Ludwig F. 2015. Hydrological Response to Climate Change of the Upper Blue Nile River Basin: Based on IPCC Fifth Assessment Report (AR5). Journal of Climatology 8 Weather Forecasting 3DOI: 10.4172/2332-2594.1000121

Gebremicael TG, Mohamed Y a., Betrie GD, van der Zaag P, Teferi E. 2013. Trend analysis of runoff and sediment fluxes in the Upper Blue Nile basin: A combined analysis of statistical tests, physically-based models and landuse maps. Journal of Hydrology 482 : 57-68 DOI: 10.1016/j.jhydrol.2012.12.023

Gebremicael TG, Mohamed YA, Van der Zaag P. 2019. Attributing the hydrological impact of different land use types and their long-term dynamics through combining parsimonious hydrological modelling, alteration analysis and PLSR analysis. Science of the Total Environment 660 : 1155-1167 DOI: 10.1016/j.scitotenv.2019.01.085

Goshime DW, Absi R, Ledésert B. 2019. Evaluation and Bias Correction of CHIRP Rainfall Estimate for Rainfall-Runoff Simulation over Lake.Hydrology 6 (68): 1-22 DOI: 10.3390/hydrology6030068

Van Griensven A, Ndomba P, Yalew S, Kilonzo F. 2012. Critical review of SWAT applications in the upper 
Nile basin countries. Hydrology and Earth System Sciences 16 (9): 3371-3381 DOI: 10.5194/hess-16-33712012

Gumindoga W, Rientjes THM, Haile AT, Dube T. 2015. Predicting streamflow for land cover changes in the Upper Gilgel Abay River Basin, Ethiopia : A TOPMODEL based approach. Physics and Chemistry of the Earth $76-78: 3-15$ DOI: 10.1016/j.pce.2014.11.012

Guzha AC, Rufino MC, Okoth S, Jacobs S, Nobrega RLB. 2018. Impacts of land use and land cover change on surface runoff, discharge and low flows: Evidence from East Africa. Journal of Hydrology: Regional Studies 15 (December 2017): 49-67 DOI: 10.1016/j.ejrh.2017.11.005

Hurkmans R, Terink W, Uijlenhoet R, Torfs P, Jacob D, Troch PA. 2010. Changes in streamflow dynamics in the Rhine basin under three high-resolution regional climate scenarios. Journal of Climate 23 (3): 679-699 DOI: $10.1175 / 2009 J C L I 3066.1$

Hyandye CB, Worqul A, Martz LW, Muzuka ANN. 2018. The impact of future climate and land use/cover change on water resources in the Ndembera watershed and their mitigation and adaptation strategies.Environmental Systems Research 7 (1) DOI: 10.1186/s40068-018-0110-4

IPCC. 2014. Climate Change 2014: Synthesis Report. Contribution of Working Groups I, II and III to the Fifth Assessment Report of the Intergovernmental Panel on Climate Change. IPCC, Geneva, Switzerland: $1-151$

Jemberie M, Gebrie T, Gebremariam B. 2016. Evaluation of Land Use Land Cover Change on Stream Flow: a Case Study Ofdedissa Sub Basin, Abay Basin, South Western Ethiopia. International Journal of Innovations in Engineering Research and Technology 3 (8): 2394-3696

Jung IW, Chang H, Moradkhani H. 2011. Quantifying uncertainty in urban flooding analysis considering hydro-climatic projection and urban development effects. Hydrology and Earth System Sciences15 (2): 617633 DOI: $10.5194 /$ hess-15-617-2011

Koch H, Biewald A, Liersch S, Azevedo JRG de, Silva GNS da, Kolling K, Fischer P, Koch R, Hattermann FF. 2015. Scenarios of climate and land-use change, water demand and water availability for the Sao Francisco River basin. Revista Brasileira de Ciencias Ambientais (Online) (36): 96-114 DOI: 10.5327/z2176947820151007

Kumar N, Tischbein B, Kusche J, Laux P, Beg MK, Bogardi JJ. 2017. Impact of climate change on water resources of upper Kharun catchment in Chhattisgarh, India. Journal of Hydrology: Regional Studies 13 (November 2016): 189-207 DOI: 10.1016/j.ejrh.2017.07.008

Lee S, Yeo I, Sadeghi AM, Mccarty GW, Hively WD, Lang MW. 2018. Comparative analyses of hydrological responses of two adjacent watersheds to climate variability and change using the SWAT model.Hydrology and Earth System Sciences 22 : 689-708 DOI: doi.org/10.5194/hess-22-689-2018

Legesse D, Abiye TA, Vallet-Coulomb C, Abate H. 2010. Streamflow sensitivity to climate and land cover changes: Meki River, Ethiopia.Hydrology and Earth System Sciences 14 (11): 2277-2287 DOI: 10.5194/hess$14-2277-2010$

Li KY, Coe MT, Ramankutty N, De Jong R. 2007. Modeling the hydrological impact of land-use change in West Africa. Journal of Hydrology337 : 258-268 DOI: 10.1016/j.jhydrol.2007.01.038

Liu J, Zhang C, Kou L, Zhou Q. 2017. Effects of Climate and Land Use Changes on Water Resources in the Taoer River. Advances in Meteorology DOI: 10.1155/2017/1031854

Mango LM, Melesse AM, McClain ME, Gann D, Setegn SG. 2011. Land use and climate change impacts on the hydrology of the upper Mara River Basin, Kenya: Results of a modeling study to support better resource management. Hydrology and Earth System Sciences 15 (7): 2245-2258 DOI: 10.5194/hess-15-2245-2011 
Marhaento H, Booij MJ, Hoekstra AY. 2018. Hydrological response to future land-use change and climate change in a tropical catchment.Hydrological Sciences Journal 63 (9): 1368-1385 DOI: $10.1080 / 02626667.2018 .1511054$

McCartney MP, Girma MM. 2012. Evaluating the downstream implications of planned water resource development in the Ethiopian portion of the Blue Nile River. Water International 37 (4): 362-379 DOI: $10.1080 / 02508060.2012 .706384$

Mekonnen D, Duan Z, Rientjes T, Disse M. 2018. Analysis of combined and isolated effects of land-use and land-cover changes and climate change on the upper Blue Nile River basin's streamflow. Hydrology and Earth System Sciences 22 (12): 6187-6207 DOI: 10.5194/hess-22-6187-2018

Melke A, Abegaz F. 2017. Impact of climate change on hydrological responses of Gumara catchment, in the Lake Tana Basin - Upper Blue Nile Basin of Ethiopia. International Journal of Water Resources and Environmental Engineering 9 : 8-21 DOI: 10.5897/ijwree2016.0658

Mishra V, Cherkauer K, Niyogi D, Lei M, Pijanowski B, Ray D, Bowling L, Yang G. 2010. A regional scale assessment of land use/land cover and climatic changes on water and energy cycle in the upper Midwest United States. International Journal of Climatology : 2011-2029 DOI: 10.1002/joc.2095

Moriasi DN, Arnold JG, Liew MW Van, Bingner RL, Harmel RD, Veith TL. 2007. Model Evaluation Guidelines for Systematic Quantification of Accuracy in Watershed Simulations. Transactions of the ASABE50 (3): 885-900 DOI: $10.1234 / 590$

Mottet A, Ladet S, Coque N, Gibon A. 2006. Agricultural land-use change and its drivers in mountain landscapes: A case study in the Pyrenees.Agriculture, Ecosystems and Environment 114 (2-4): 296-310 DOI: $10.1016 /$ j.agee.2005.11.017

MoWIE. 1998. Abbay River Basin Integrated Development Mater Plan Project: Phase 2, vol. VI, Water Resources Development, Part 2, Large Irrigation and Hydropower Dams. Ministry of Water, Irrigation, and Electricity

MoWIE. 2008. Gumara Irrigation Project Feasibility Study Report.

Ministry of Water, Irrigation, and Electricity, Addis Ababa, Ethiopia.

Mwangi HM, Julich S, Patil SD, McDonald MA, Feger KH. 2016. Relative contribution of land use change and climate variability on discharge of upper Mara River, Kenya. Journal of Hydrology: Regional Studies 5 : 244-260 DOI: 10.1016/j.ejrh.2015.12.059

Neitsch S., Arnold J., Kiniry J., Williams J. 2011. Soil \& Water Assessment Tool: Theoretical Documentation Version 2009. Texas A \& $M$ University, USA

Nigatu ZM, Rientjes T, Haile AT. 2016. Hydrological Impact Assessment of Climate Change on Lake Tana's Water Balance, Ethiopia. American Journal of Climate Change 05 (01): 27-37 DOI: 10.4236/ajcc.2016.51005

Nyssen J, Poesen J, Moeyersons J, Deckers J, Haile M, Lang A. 2004. Human impact on the environment in the Ethiopian and Eritrean highlands - A state of the art. Earth-Science Reviews 64 (3-4): 273-320 DOI: 10.1016/S0012-8252(03)00078-3

Pandey BK, Gosain AK, Paul G, Khare D. 2017. Climate change impact assessment on hydrology of a small watershed using semi-distributed model. Applied Water Science 7 (4): 2029-2041 DOI: 10.1007/s13201-0160383-6

Polanco EI, Fleifle A, Ludwig R, Disse M. 2017. Improving SWAT model performance in the upper Blue Nile Basin using meteorological data integration and subcatchment discretization. Hydrology and Earth System Sciences 21 (9): 4907-4926 DOI: 10.5194/hess-21-4907-2017 
Rahbeh M, Chanasyk D, Miller J. 2013. Modelling the effect of irrigation on the hydrological output from a small prairie watershed.Canadian Water Resources Journal 38 (4): 280-295 DOI: $10.1080 / 07011784.2013 .849856$

Rahman K, da Silva AG, Tejeda EM, Gobiet A, Beniston M, Lehmann A. 2015. An independent and combined effect analysis of land use and climate change in the upper Rhone River watershed, Switzerland. Applied Geography 63 : 264-272 DOI: 10.1016/j.apgeog.2015.06.021

Rahman MTU, Tabassum F, Rasheduzzaman M, Saba H, Sarkar L, Ferdous J, Uddin SZ, Zahedul Islam AZM. 2017. Temporal dynamics of land use/land cover change and its prediction using CA-ANN model for southwestern coastal Bangladesh. Environmental Monitoring and Assessment189 (11): 1-18 DOI: $10.1007 / \mathrm{s} 10661-017-6272-0$

Setegn SG, Srinivasan R, Dargahi B. 2008. Hydrological Modelling in the Lake Tana Basin, Ethiopia Using SWAT Model. The Open Hydrology Journal 2 (1): 49-62 DOI: 10.2174/1874378100802010049

SGZOA. 2016. Agriculture production management document of South Gondor Zone (Unpublished report). South Gondar Zone Office of Agriculture, Debre Tabor, Ethiopia

Sisay K, Thurnher C, Hasenauer H. 2017. Daily climate data for the Amhara region in Northwestern Ethiopia. International Journal of Climatology 37 (6): 2797-2808 DOI: 10.1002/joc.4880

Sunde MG, He HS, Hubbart JA, Urban MA. 2018. An integrated modeling approach for estimating hydrologic responses to future urbanization and climate changes in a mixed-use midwestern watershed. Journal of Environmental Management 220 (May): 149-162 DOI: 10.1016/j.jenvman.2018.05.025

Taye MT, Willems P, Block P. 2015. Implications of climate change on hydrological extremes in the Blue Nile basin: A review. Journal of Hydrology: Regional Studies 4 : 280-293 DOI: 10.1016/j.ejrh.2015.07.001

Teferi E, Bewket W, Uhlenbrook S, Wenninger J. 2013. Understanding recent land use and land cover dynamics in the source region of the Upper Blue Nile, Ethiopia: Spatially explicit statistical modeling of systematic transitions. Agriculture, Ecosystems and Environment165 : 98-117 DOI: 10.1016/j.agee.2012.11.007

Teklay A, Dile YT, Asfaw DH, Bayabil HK, Sisay K. 2019. Impacts of land surface model and land use data on WRF model simulations of rainfall and temperature over Lake Tana Basin, Ethiopia. Heliyon 5(9): 1-14 DOI: 10.1016/j.heliyon.2019.e02469

Teklay A, Dile YT, Setegn SG, Demissie SS, Asfaw DH. 2018. Evaluation of static and dynamic land use data for watershed hydrologic process simulation : A case study in Gummara watershed, Ethiopia. Catena 172 (August 2018): 65-75 DOI: 10.1016/j.catena.2018.08.013

Woldesenbet T, Elagib NA, Ribbe L, Heinrich J. 2018. Catchment response to climate and land use changes in the Upper Blue Nile sub-basins, Ethiopia. Science of the Total Environment 644 : 193-206 DOI: $10.1016 /$ j.scitotenv.2018.06.198

Woldesenbet TA, Elagib NA, Ribbe L, Heinrich J. 2017. Hydrological responses to land use/cover changes in the source region of the Upper Blue Nile Basin, Ethiopia. Science of the Total Environment575 : 724-741 DOI: $10.1016 /$ j.scitotenv.2016.09.124

World Bank. 2019. Climate Change Knowledge Portal. Retrieved 12/07/2019 2019, from https://climateknowledgeportal.worldbank.org/country/ethiopia/climate-data-projections. DOI: 10.1016/j.jhydrol.2008.05.012

Wulong B, Pengfei D, Tie L, Anming B, Min L, Mujtaba H, Chengxin Q. 2018. Simulating hydrological responses to climate change using dynamic and statistical downscaling methods: a case study in the Kaidu River Basin, Xinjiang, China. Journal of Arid Land 10 (6): 905-920 DOI: 10.1007/s40333-018-0068-0

Yan R, Cai Y, Li C, Wang X, Liu Q. 2019. Hydrological responses to climate and land use changes in a watershed of the Loess Plateau, China.Sustainability 11 (5): 1-19 DOI: 10.3390/su11051443 
Yin J, He F, Jiu Xiong Y, Yu Qiu G. 2017. Effects of land use/land cover and climate changes on surface runoff in a semi-humid and semi-arid transition zone in northwest China. Hydrology and Earth System Sciences 21 (1): 183-196 DOI: 10.5194/hess-21-183-2017
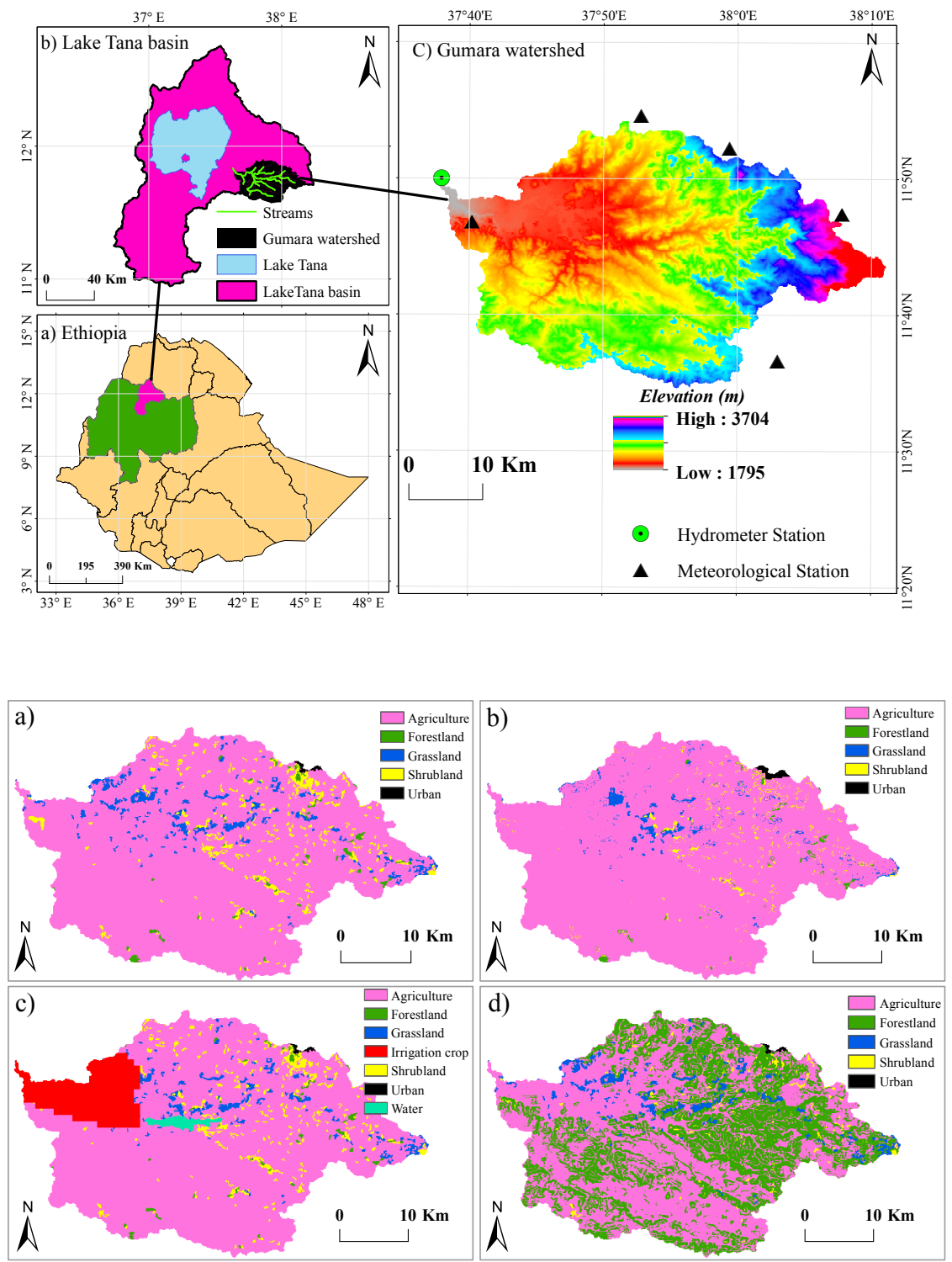

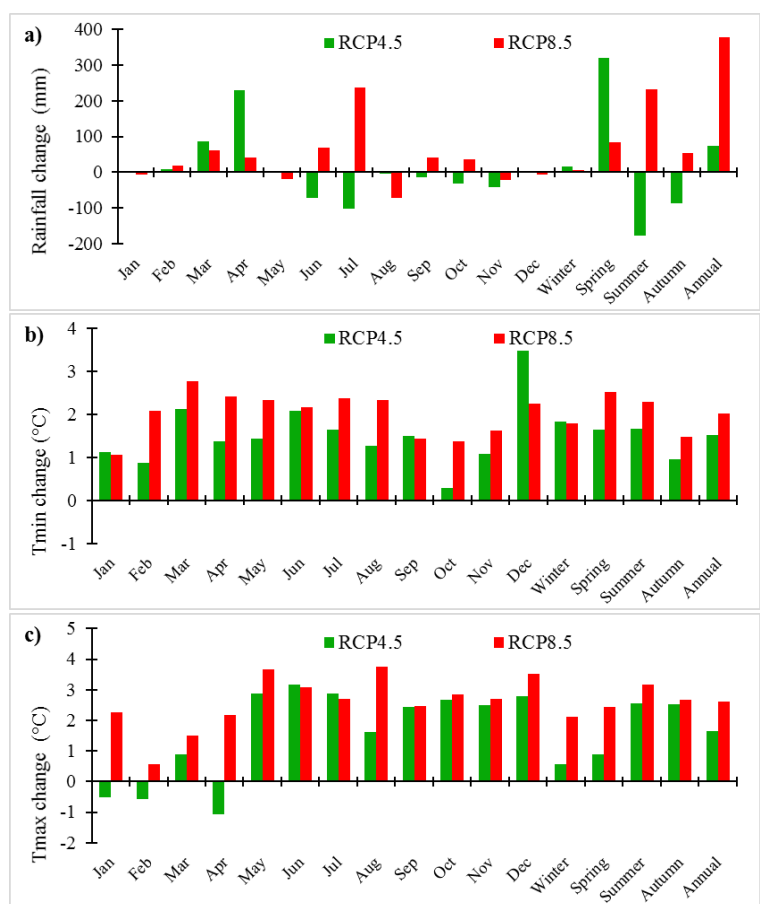

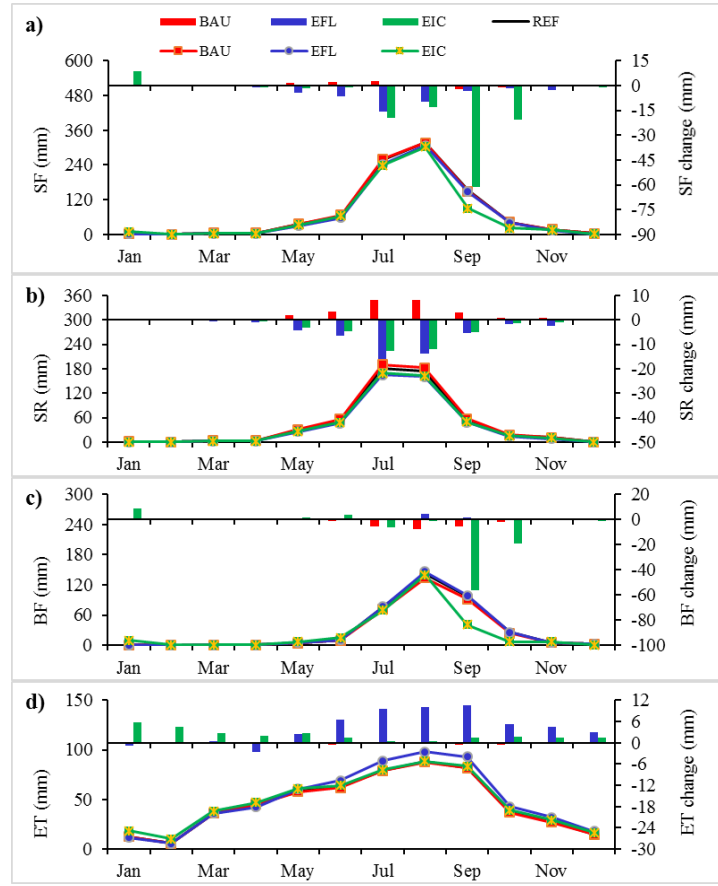

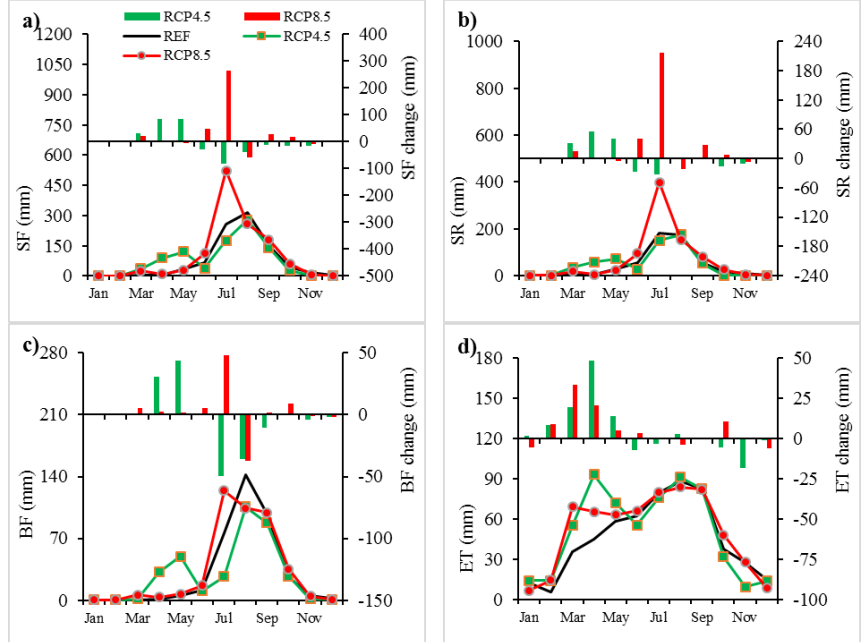

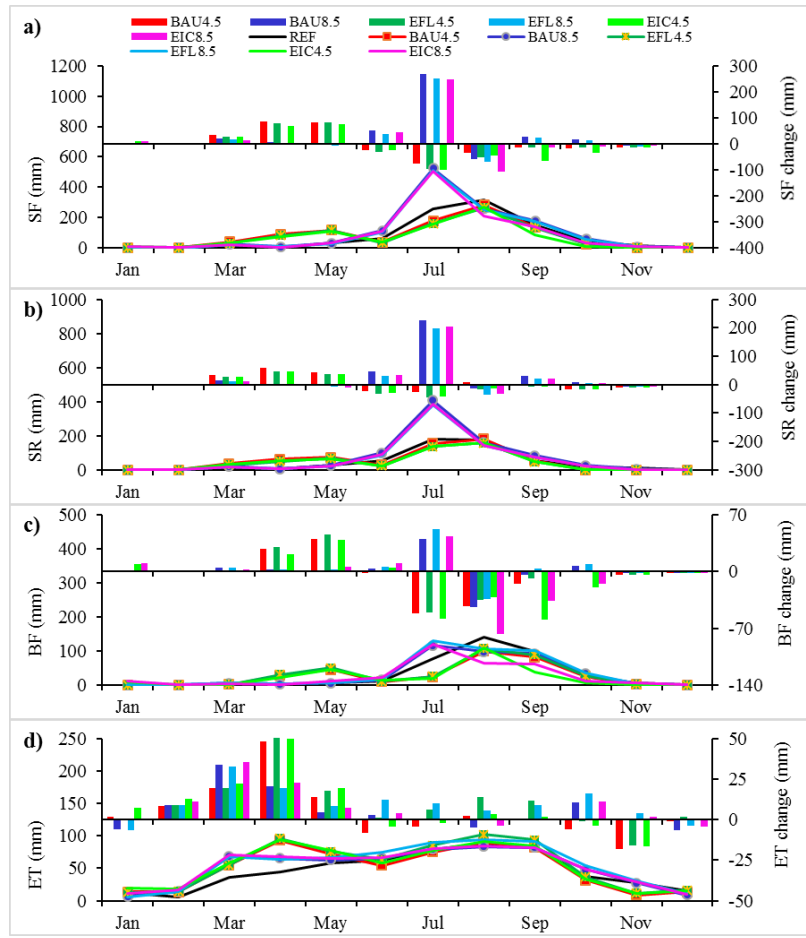

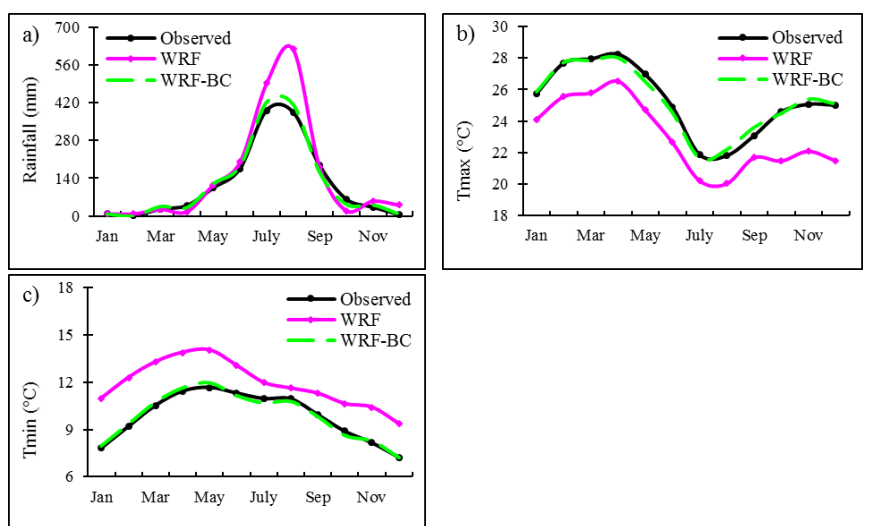

\section{Hosted file}

Table 1.docx available at https://authorea.com/users/354012/articles/477700-impacts-ofclimate-and-land-use-change-on-hydrological-response-in-gumara-watershed-ethiopia

\section{Hosted file}

Table 2.docx available at https://authorea.com/users/354012/articles/477700-impacts-ofclimate-and-land-use-change-on-hydrological-response-in-gumara-watershed-ethiopia

\section{Hosted file}

Table 3.docx available at https://authorea.com/users/354012/articles/477700-impacts-ofclimate-and-land-use-change-on-hydrological-response-in-gumara-watershed-ethiopia

\section{Hosted file}


Table 4.docx available at https://authorea.com/users/354012/articles/477700-impacts-ofclimate-and-land-use-change-on-hydrological-response-in-gumara-watershed-ethiopia

\section{Hosted file}

Table 5.docx available at https://authorea.com/users/354012/articles/477700-impacts-ofclimate-and-land-use-change-on-hydrological-response-in-gumara-watershed-ethiopia

\section{Hosted file}

Table 1A.docx available at https://authorea.com/users/354012/articles/477700-impacts-ofclimate-and-land-use-change-on-hydrological-response-in-gumara-watershed-ethiopia 